\title{
Auroral electrojet oval
}

\author{
Geng-Xiong Chen ${ }^{1}$, Wen-Yao Xu ${ }^{1}$, Zi-Gang Wei ${ }^{1}$, B.-H. Ahn ${ }^{2}$, and Y. Kamide ${ }^{3}$ \\ ${ }^{1}$ Institute of Geology and Geophysics, Chinese Academy of Sciences, Beijing 100029, China \\ ${ }^{2}$ Department of Earth Science, Teachers College, Kyungpook National University, 1370 Sankyuk-dong, Buk-gu, Daegu, 702-701, Korea \\ ${ }^{3}$ Solar-Terrestrial Environment Laboratory, Nagoya University, Honohara 3-13, Toyokawa, Aichi 442-8507, Japan
}

(Received October 15, 2002; Revised May 20, 2003; Accepted May 20, 2003)

\begin{abstract}
The auroral electrojet is enhanced in the polar ionosphere associated with charged particle precipitation and fieldaligned currents during substorms. In this paper the geometry of the elctrojet is determined by using the ionospheric equivalent current systems for every 5 minutes during March 18 and 19, 1978. The latitudinal and local time shifts of the oval are examined. Possible relationship of the electrojet oval with expansion of the auroral oval and the fieldaligned current belts during substorms are discussed. The electrojet oval in the polar region consists of westward and eastward electrojets, varying with AE index. As the magnetic activity increases, the westward electrojet has distinct latitudinal shifts in different local time sectors: it shifts poleward around the midnight (23:00-03:00 MLT), while moves equatorward in the morning sector (03:00-10:00 MLT) and afternoon sector (20:00-23:00 MLT. The eastward electrojet includes two insulated parts: a higher-latitude part around $80^{\circ}$ latitude in the nighttime sector (21:00-03:00 MLT) and a lower-latitude part between $60^{\circ}-70^{\circ}$ latitudes in other local time sectors. As AE index increases, the higher-latitude part of the eastward electrojet expands eastward from 03:00 to 08:00 MLT, while the lower-latitude part shows a equatorward shift in the afternoon sector, which is more or less similar to the westward electrojet.
\end{abstract}

Key words: Auroral electrojet, AE index, substorm.

\section{Introduction}

The current system in the polar region, including an intense auroral electrojet, is mainly driven by particle precipitation and field-aligned currents, although the dynamo process has minor contribution (Akasofu, 1972; Matsushita and $\mathrm{Xu}, 1982$; Newell, 2001; Lui, 2001). The field-aligned current belt expands both equatorward and poleward during magnetic disturbed condition (Iijima and Potemra, 1976a, b; 1978). Akasofu (1972) studied extensively auroras and pointed out that the auroral oval expands both equatorward and poleward during magnetic substorms. Kamide and Matsushita $(1979 \mathrm{a}, \mathrm{b})$ calculated the ionospheric current system caused by field-aligned currents, and showed how the current pattern in the polar region, especially the electrojet, strongly depends upon the distribution of the field-aligned currents and ionospheric conductivity. Using the method of natural orthogonal components, Sun et al. $(1998,2000)$ separated the eigen mode representing auroral electrojet, which is located between $65^{\circ}-70^{\circ}$ latitude around the midnight sector. However, examination of latitudinal profiles of magnetic disturbances using meridian chain data shows very complicated behaviors instead of systematic latitudinal shift.

In this paper the ionospheric equivalent current systems in the polar region, constructed at 5-minute interval for March 18-19, 1978, are used to examine latitudinal and local time shift of the electrojet oval for different magnetic activities. Possible relationship of the electrojet shift with the latitu-

Copy right (c) The Society of Geomagnetism and Earth, Planetary and Space Sciences (SGEPSS); The Seismological Society of Japan; The Volcanological Society of Japan; The Geodetic Society of Japan; The Japanese Society for Planetary Sciences. dinal expansion of the field-aligned current belt and auroral oval is discussed.

\section{Data Analysis}

The magnetic variations recorded at a meridian chain of magnetometers in the polar region are usually used to study the auroral electrojet. The latitude of the electrojet center is determined by the maximum deviation of $\mathrm{H}$ component or the zero Z component (Kamide and Akasofu, 1974, 1983; Akasofu et al., 1983; Feldstein et al., 1997). It is expected that the electrojet belt would shift in latitude, when substorms occur. In some cases, unfortunately, it is hard to obtain definite results by a single meridian chain.

An examination is made using the magnetic data from Alaska chain for 38 days in 1998, when substorms occur. In Fig. $1 \mathrm{AU}$ and AL indices are shown for the 38 days. The latitude of the westward electrojet determined by the maximum $\mathrm{H}$ component is shown in the upper part. It is hard to recognize a definite relationship between the latitude of the electrojet center and magnetic activity.

It seems to be necessary to use the data at least in the whole polar region to definitely determine the auroral electrojet, including its location and intensity. Kamide et al. (1982a, b) extensively collected the magnetic records from a total of 71 stations in the north polar region during the International Magnetospheric Study (IMS), and calculated the ionospheric equivalent current functions with time resolution of 5 minutes on the basis of this IMS dataset. This is a very heavy work so that the calculations have been made only for three days, 17, 18 and 19, March 1978. These data supply useful information for studying the dependence of the 


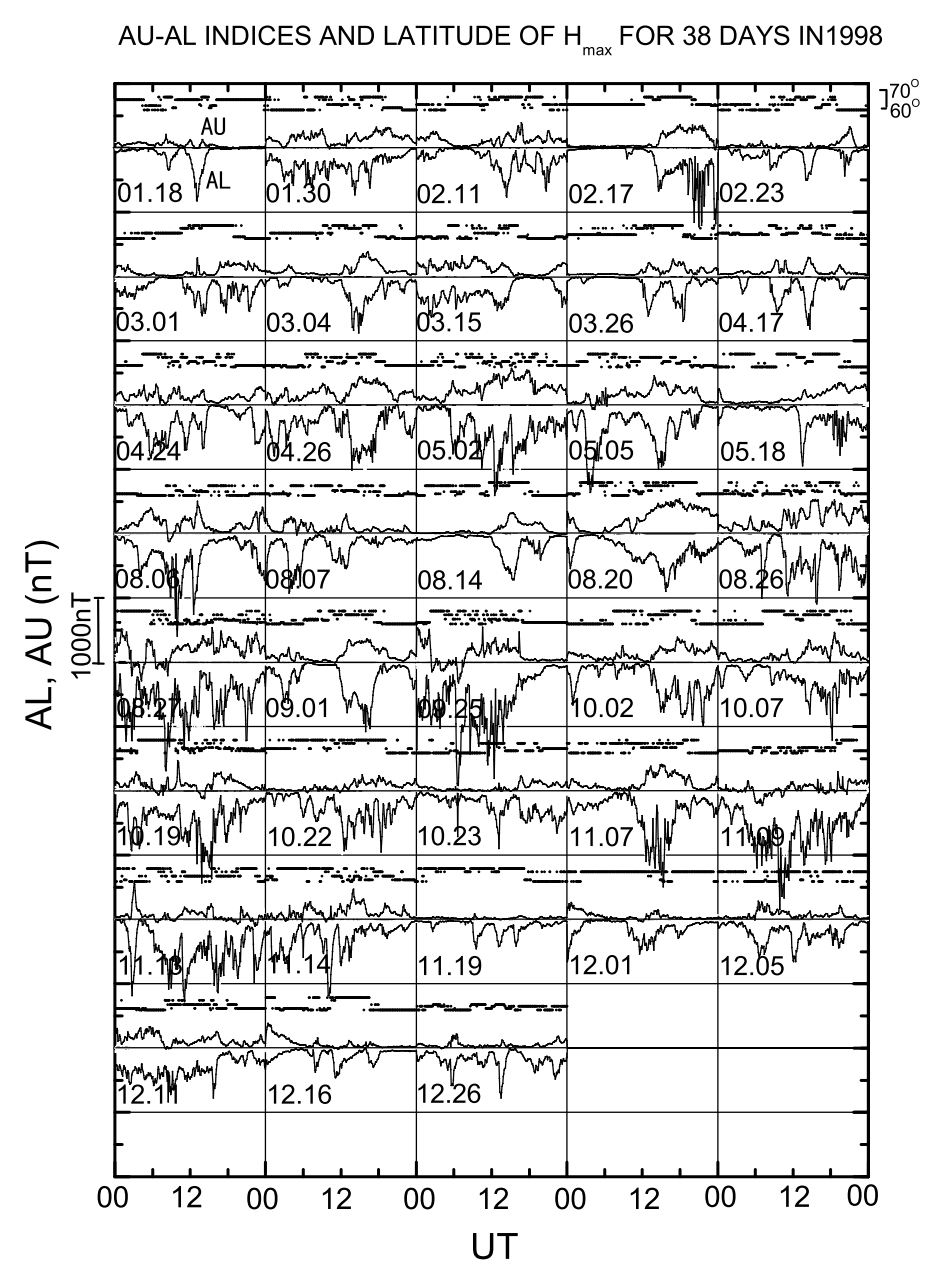

Fig. 1. AU and AL indices and the latitude of the westward electrojet center determined by the maximum $\mathrm{H}$ component for 38 days, 1998.

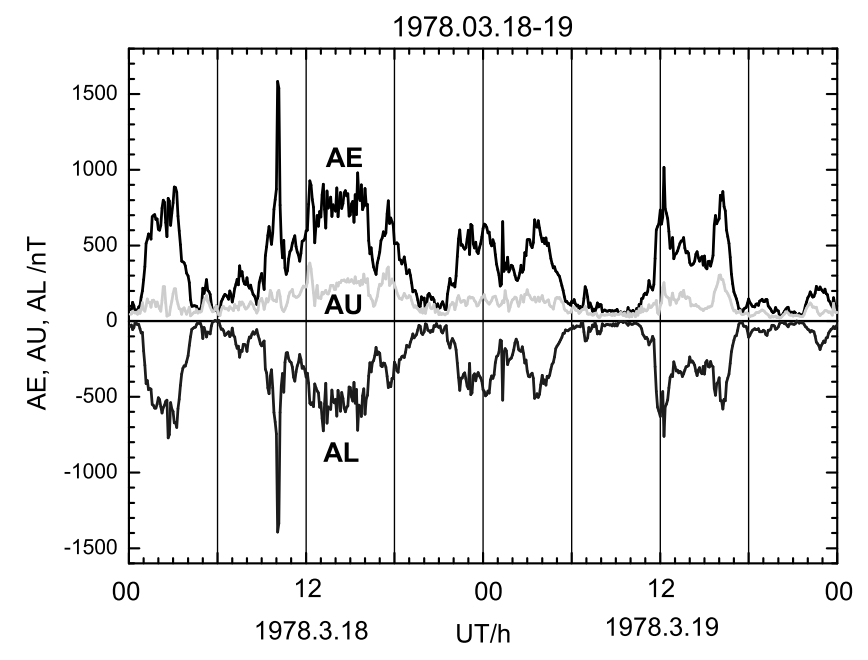

Fig. 2. Auroral electrojet indices AE, AL and AU during March 18-19, 1978.

current system configuration on solar wind parameters and magnetic activity, and have been widely used to study auroral electrojet indices and other substorm-related phenomena. Since there are no complete solar wind data on 17, March, the data on 18 and 19, March have been more frequently used (see Sun et al., 1998, 2000).

In this paper 576 current functions for March 18-19, 1978 are used to study the auroral electrojet. The magnetic activity 


\section{Current system and current density for 15:20UT of March 18, 1978}

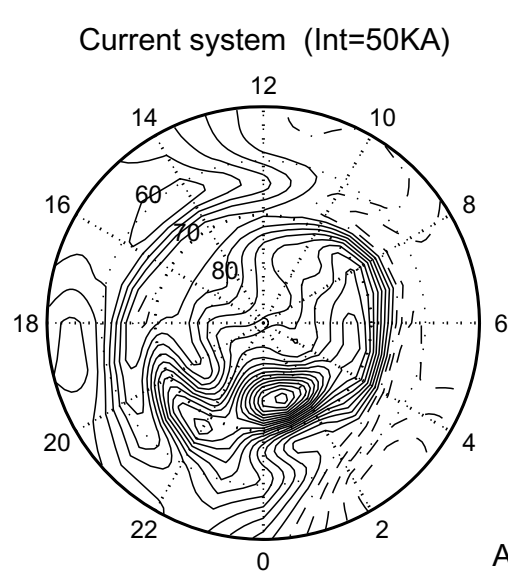

(a)

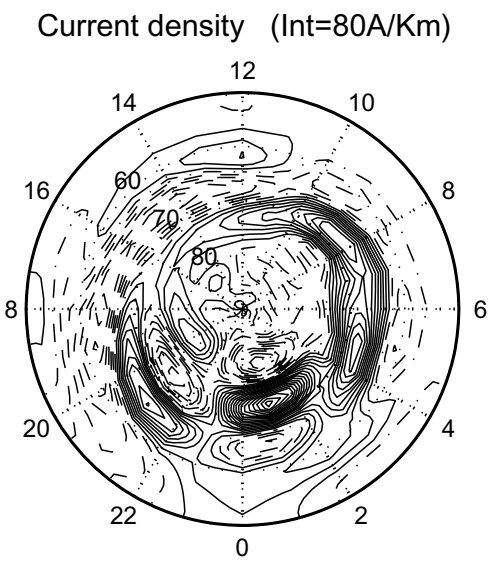

(b)

Fig. 3. Ionospheric equivalent current system (a) and east-westward current density (b) for UT 15:20 of March 18, 1978.

during this two-day period is shown in Fig. 2 by 5 -minute averaged auroral electrojet indices $\mathrm{AE}, \mathrm{AL}$ and $\mathrm{AU}$. In the two-day duration there are at least 4 disturbed periods, each of which includes one or more substorms. The maximum 5-minute averaged AE is 1584 nT at 10:05 UT of March 18.

As an example, Figure 3(a) shows the ionospheric equivalent current system at 15:20 UT on March $18(\mathrm{AE}=815$ $\mathrm{nT}, \mathrm{AL}=-542 \mathrm{nT}, \mathrm{AU}=293 \mathrm{nT}$. The contour interval is $50 \mathrm{kA}$. A two-cell current pattern dominates in the polar region with an enhanced westward electrojet in the midnightmorning sector around $70^{\circ}$ latitude.

Figure 3(b) shows the east-westward current density calculated from the current function. In this paper the westward (eastward) current is defined as positive (negative) and represented by solid (dashed) contour lines. It is noted in Fig. 3(b) that the westward electrojet distributes mainly along an ovalshaped belt between $60^{\circ}$ and $80^{\circ}$ latitudes, and latitudinal variation of the current density is dependent on local time. Similarly, the eastward electrojet distributes mainly in another oval-shaped belt, which consists of two insulated parts, one at lower latitudes $\left(60^{\circ}-65^{\circ}\right)$ from early morning to afternoon and another at higher latitudes (around $80^{\circ}$ ) in the midnight sector.

In order to study the variation of the electrojet with magnetic activity, all 576 current patterns are divided into 5 groups for $\mathrm{AE}=0-200,200-400,400-600,600-800$ and $>800 \mathrm{nT}$. The average current systems for each group are shown in the upper row of Fig. 4. It is noted that a two-cell current structure exists for all cases, and both westward and eastward electrojets are enhanced as AE index increases.

The east-westward current density $J$ (unit: $A / \mathrm{km}$ is calculated from the current functions and shown in the lower row of Fig. 4. It is noted in the figure that in the nighttime-tomorning sector an intensive westward electrojet, $J_{W}$, flows around $70^{\circ}$ latitude, and an eastward current $J_{E}$ flows at high latitudes with the central location at $80^{\circ}$ latitude. In the afternoon sector a low-latitude eastward electrojet and diffusive high-latitude westward currents composite the afternoon current cell.

\section{Auroral Electrojet Oval}

The general shape of the electrojet oval can be roughly described by the maximum electrojet $J_{W \max }$ or $J_{E \max }$ for each local time, as shown in Fig. 5. It is noted in Fig. 5(a) that as AE index increases, the westward electrojet oval has distinct latitudinal shift for different local time sectors. Namely, the oval steadily shifts poleward around the midnight (23:0003:00 MLT), while it moves equatorward in the morning sector (03:00-10:00 MLT) and afternoon section (20:00-23:00 MLT.

The eastward electrojet oval in Fig. 5(b) includes two separated parts, a higher-latitude part around $80^{\circ}$ latitude in the midnight-morning section (21:00-03:00 MLT) and a lowerlatitude part between $60^{\circ}-70^{\circ}$ latitudes in other local time sections. The higher-latitude part of the eastward electrojet oval expands eastward from 03:00 MLT to 08:00 with increasing AE index without obvious latitudinal movement, while the lower-latitude part shows a equatorward shift in the afternoon section, more or less similar to the westward electrojet.

\section{Local Time Dependence of the Electrojets}

It is noted in the lower panel of Fig. 4 that $J_{W}$ and $J_{E}$ of the average auroral electrojet ovals vary with local time. The maximum densities $J_{W \max }$ and $J_{E \max }$ at each MLT are shown in Fig. 6 for 5 activity levels. The maximum westward electrojet density (Fig. 6(a)) occurs in the morning (about 00-03 MLT) for disturbed cases (AE > $400 \mathrm{nT}$ ), while it occurs around 06 MLT for moderate disturbances (AE = 200-400 nT) and around noon for quiet period (AE $<200$ nT. The maximum eastward electrojet density (Fig. 6(b)) occurs around the midnight for the high-latitude part, and around 15 MLT for the low-latitude part.

In order to judge how well the AE index represents the maximum electrojet density, all 576 samples are examined in detail. The maximum westward electrojet $J_{W \max }$ and eastward electrojet $J_{E \text { max }}$ are found for each UT instant. Figure 7 shows a fine linear correlation of the $J_{W \text { max }}$ with AE index, $J_{W \max }(A / \mathrm{km})=93.41+1.34 \mathrm{AE}(\mathrm{nT})$ with correlation co- 

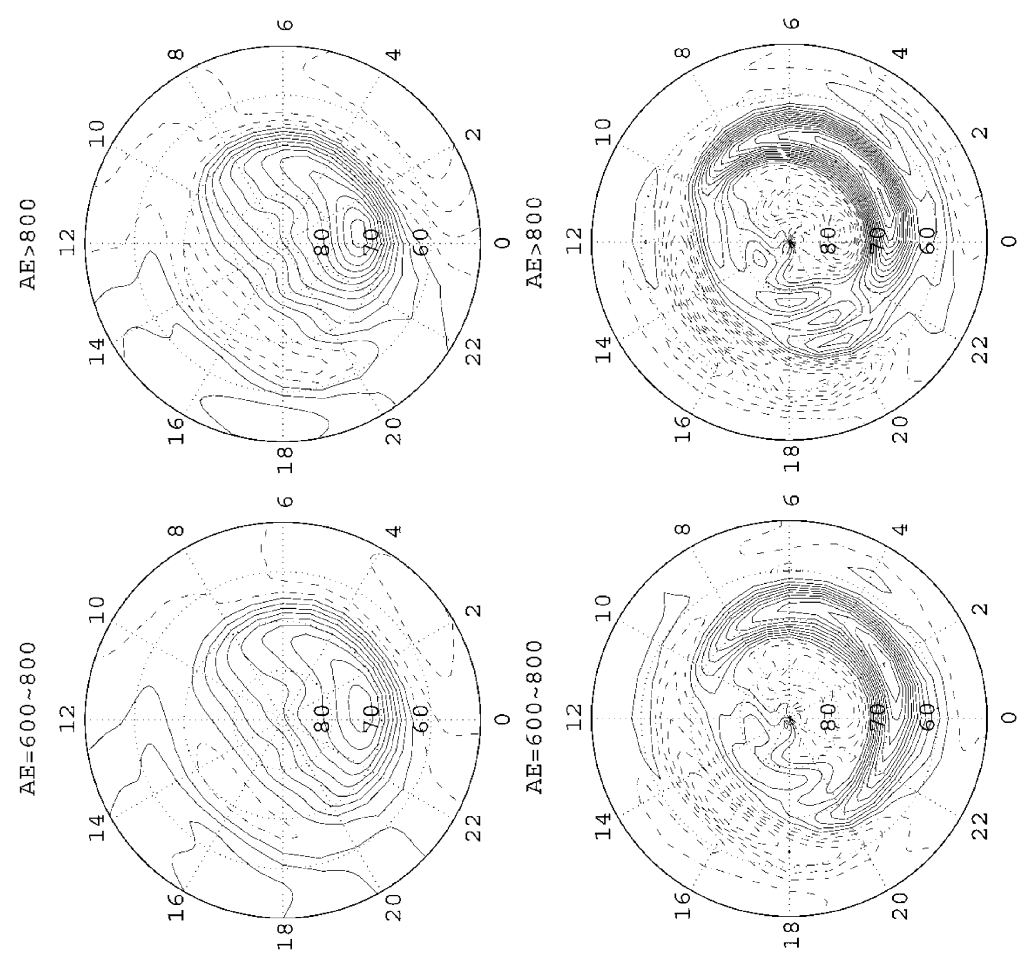

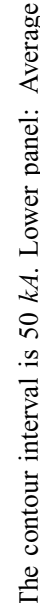
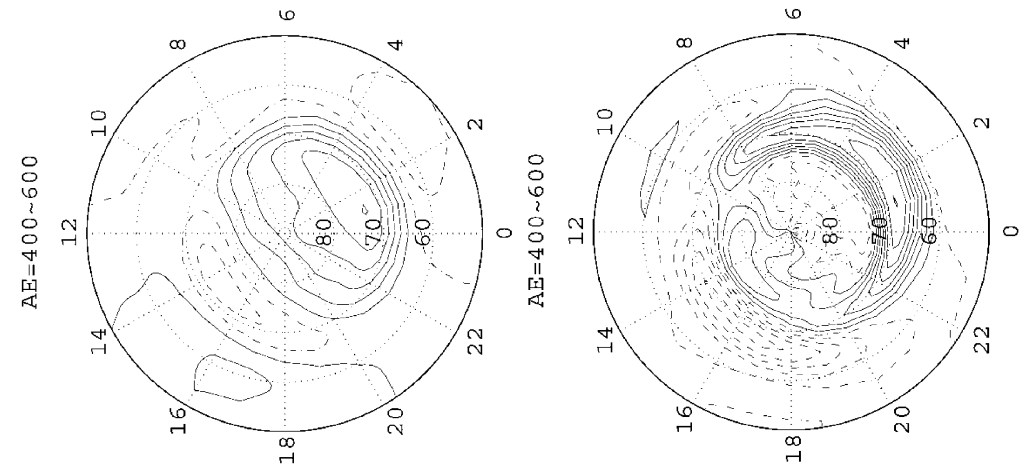

离
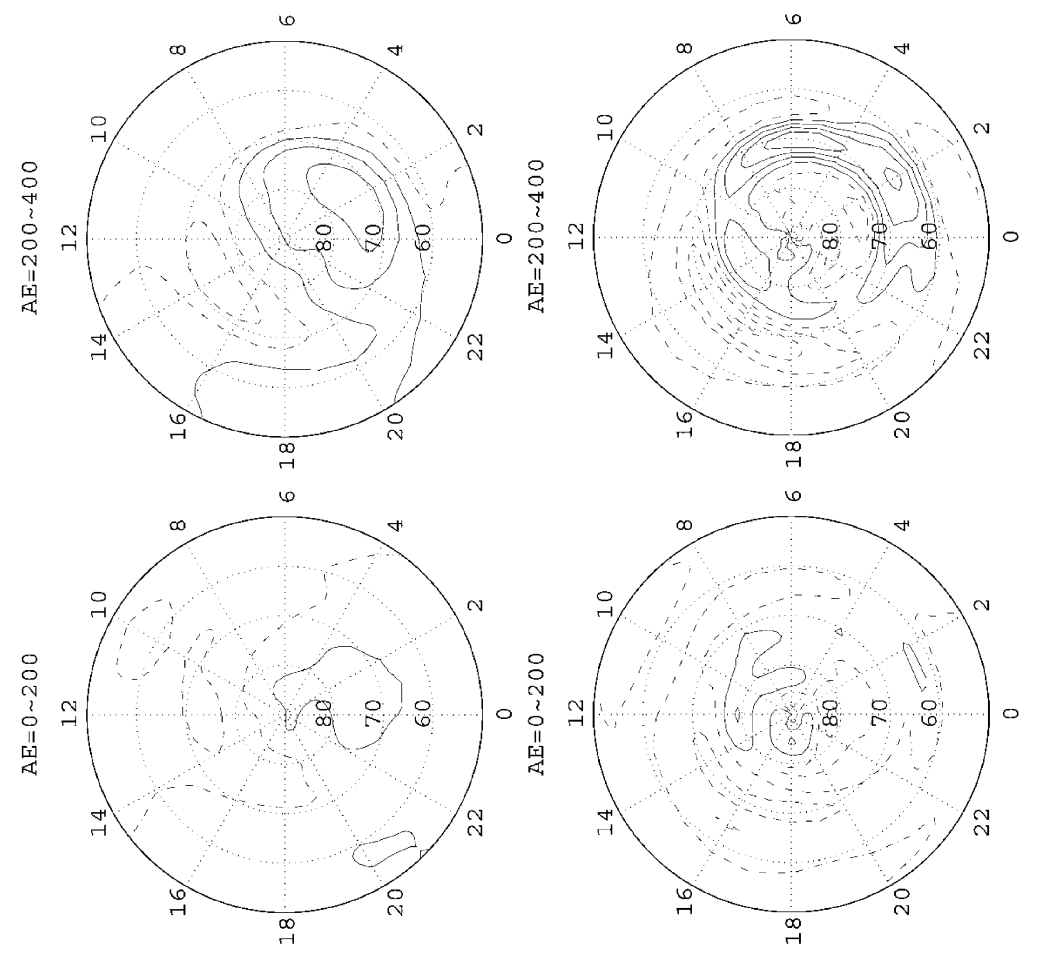

$(\forall Y O S=\lfloor\mathrm{U} \mid)$

$(m>/ \forall O S=1 U 1)$

سəנsКs дUәגנnכ

К!!suәр ұuәлınכ 


\section{AURORAL ELECTROJET OVAL FOR DIFFERENT AE RANGES 1978.3.18-19}

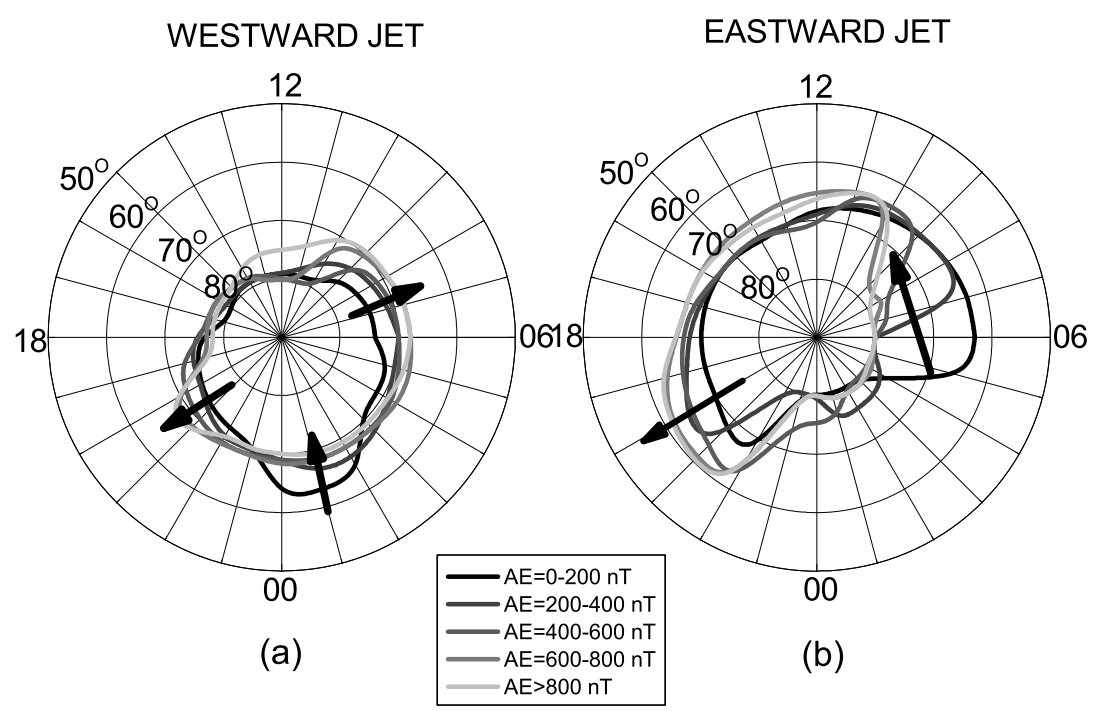

Fig. 5. Westward and eastward electrojet ovals for different AE ranges. Arrows indicate the oval's movements with increasing AE index.
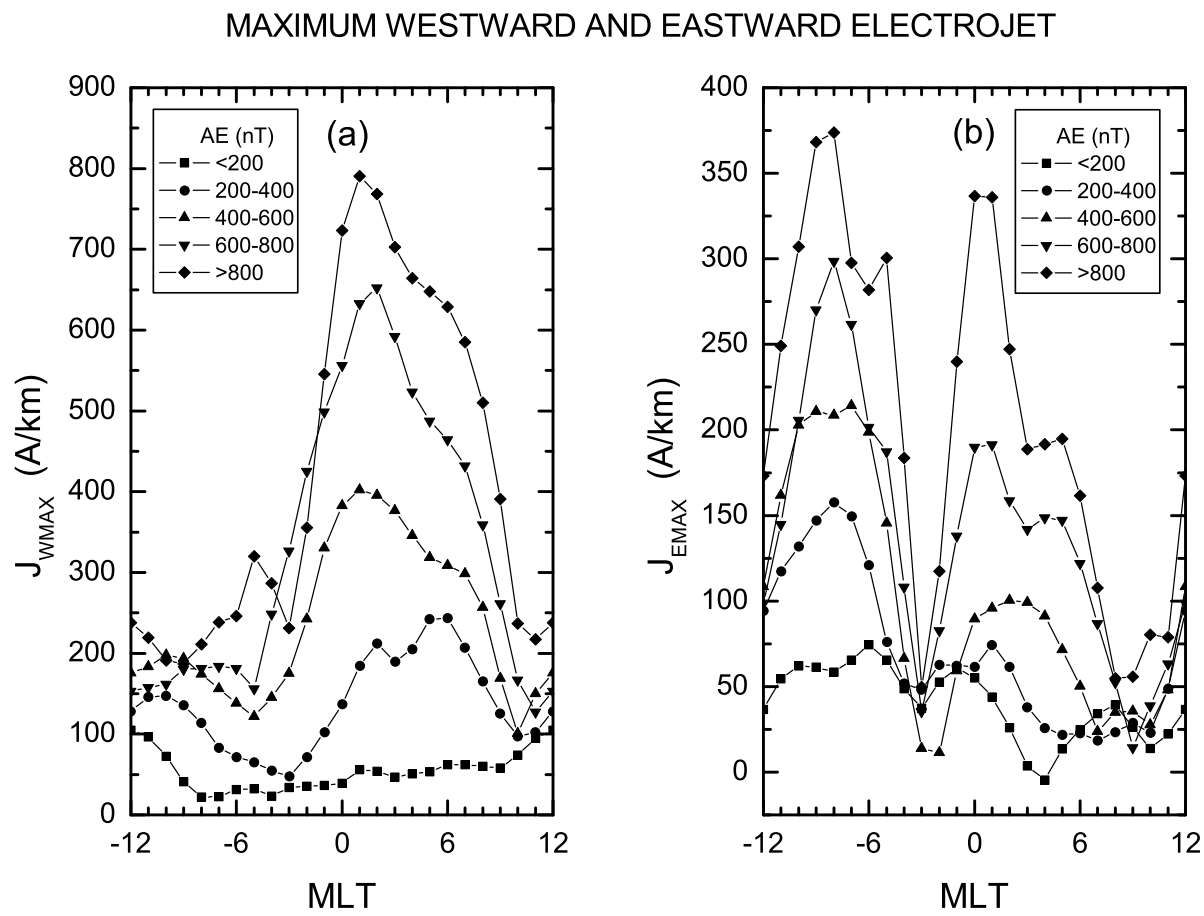

Fig. 6. The maximum westward electrojet $J_{W \max }$ (a) and eastward electrojet $J_{E \max }$ (b) in the electrojet ovals for different activity levels.

efficient 0.925 . Similar correlation is obtained for the eastward electrojet $J_{E \max }, J_{E \max }(A / \mathrm{km})=-164.30-0.49 \mathrm{AE}$ (nT) with correlation coefficient 0.768 .

\section{Discussions and Conclusion}

The dataset of current functions by Kamide et al. (1982a, b) is the best data source until now, however, it should be pointed out that the results obtained in this paper are preliminary, since only 576 samples of two days have been used, that are not sufficient for detailed statistical study. Fortunately, these data include various activity levels from quiet condition, through weak and moderate disturbances to se- vere substorms, which allow us to group the data according activity.

As analyzed by Kamide et al. (1982a, b), ununiformity and sparseness of stations in some areas, for instance, in the very high latitudinal region and East Siberian sector, certainly result in some bias and restrict the spatial resolution. Fortunately, the stations are much denser in latitude than in longitude, consequently, the spatial resolution in latitude is much better than in longitude, that is favorable to our main concern - the latitudinal shift of the electrojet oval.

The variations of the auroral electrojet ovals with AE index may be explained as follows. The westward auroral elec- 


\section{MAXIMUM ELECTROJET DENSITY AND ITS MLT}

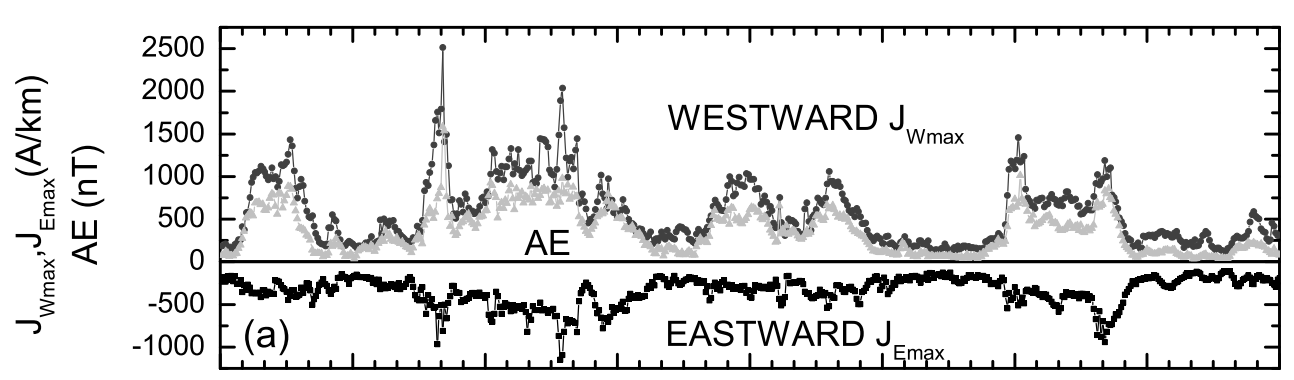

Fig. 7. Comparison of the maximum westward and eastward electrojets with AE index.

(a)

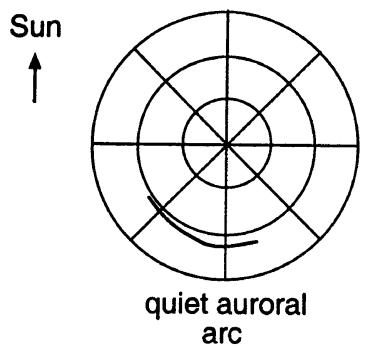
arc

(b) Sun
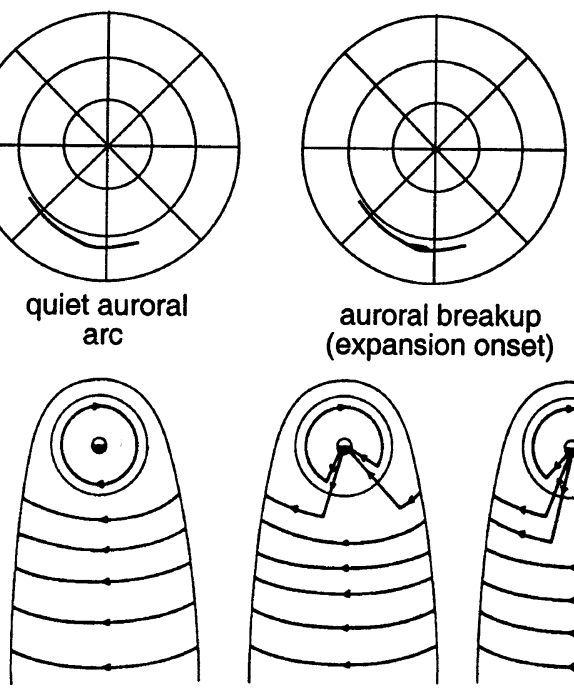

quiet time
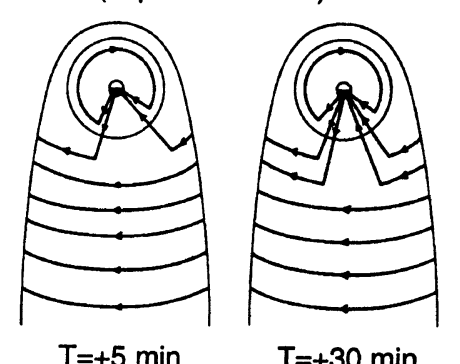

$$
\mathrm{T}=+30 \mathrm{~min}
$$

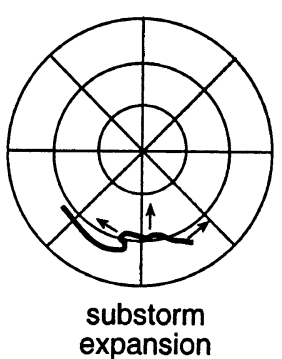

(c)

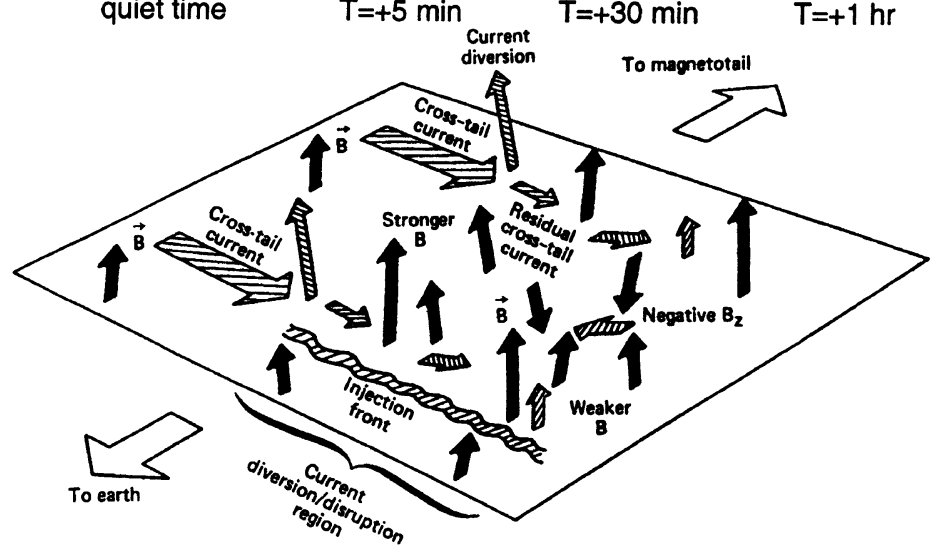

Fig. 8. Disruption of the cross-tail currents and the evolution of the substorm current wedge.

trojet around midnight is considered to be intimately tied to the diversion of the cross-tail current to the ionosphere, which is referred to as substorm current wedge. Figure 8 illustrates schematically the evolution of the substorm current wedge, accompanied within it by a significant increase of magnetic field normal to the equatorial plane, known as dipolization (Akasofu, 1972; Lui, 2001). It is noted that disruption of the cross-tail current may take place firstly at distances $X=-6 R_{E^{-}}-10 R_{E}$. The blocked part of the cross-tail current must find a new circuit, and the obvious one would be the polar ionosphere circuit. In this way, a substorm current wedge is formed (Atkinson, 1967; McPherron et al., 1973). Along with tailward expansion of the blocked part of the cross-tail currents, the ionospheric partner of the current wedge as well as the westward electrojet will move poleward.

As for the equatorward expansion of the electrojet oval in the afternoon and morning sectors, it might be related with an earthward expansion of the partial ring currents.

It should be emphasized that the equivalent currents are different from the true currents, especially close to where the real currents connect to field-aligned currents. The currents at high latitudes are three-dimensional in nature. The north-south component of the magnetic perturbations can 
arise from the east-west electrojets in the ionosphere as well as a north-south oriented sheet of field-aligned currents. The higher-latitude part around $80^{\circ}$ latitude in the nighttime sector is most likely an equivalent return current generated by the divergence of the westward current close to the Harang discontinuity or at the edges of the substorm current wedge. This can cause eastward equivalent return currents that are larger on its poleward side than on its equatorward side and may partly result in the eastward shift of the eastward electrojet with AE increase during the stronger substorm. It is impossible, in principle, to separate these two different effects by using magnetic observations made on the Earth's surface alone (Kamide, 1988). Therefore, the scheme in Fig. 8 only gives a tentative relation between the expansion of the auroral electrojet oval and the development of the magnetotail current interruption. More comprehensive study by using much more data, such as SuperDARN data, and advanced technique, such as AMIE, is needed (Greenwald et al., 1995; Richmond, 1992; Lu et al., 1994).

The main results obtained in this paper is summarized as follows:

(1) The auroral electrojet oval consists of westward and eastward electrojets, the shapes and locations of which vary with AE index.

(2) The westward electrojet oval has distinct latitudinal shift in different local time sectors. Namely, the oval shifts poleward around the midnight (23:00-03:00 MLT), while moves equatorward in the morning sector (03:0010:00 MLT) and afternoon sector (20:00-23:00 MLT.

(3) The eastward electrojet oval includes two separated parts: a higher-latitude part around $80^{\circ}$ latitude in the nighttime sector (21:00-03:00) and a lower-latitude part between $60^{\circ}-70^{\circ}$ latitudes in other local time sectors. The higherlatitude part of the eastward electrojet expands eastward with increasing AE index, while the lower-latitude part shows an equatorward shift in the afternoon sector, more or less similar to the westward electrojet.

(4) The auroral electrojet is closely related to a diversion of the cross-tail current to the ionosphere, or the substorm current wedge in the magnetosphere.

Acknowledgments. We would like to thank the team of Alaska chain for providing the geomagnetic data. Also we thank WDCC2 for supplying auroral indexes. This work was supported by the National Key Basic Research Science Foundation of China (Grant No. G2000078406) and the National Natural Science Foundation of China (Grant No. 40236058).

\section{References}

Akasofu, S.-I., Magnetospheric substorms: A model, in Solar-Terrestrial Physics, Part 3, edited by E. R. Dyer, 131 pp., D. Reidel, Norwell, Mass., 1972.

Akasofu, S.-I., B. H. Ahn, Y. Kamide, and J. H. Allen, A note on the accuracy of the auroral electrojet indices, J. Geophys. Res., 88, 57695772, 1983.

Atkinson, G. J., An approximate flow equation for geomagnetic flux tubes and its application to polar substorms, J. Geophys. Res., 72, 5373-5382, 1967.

Feldstein, Y. I., A. Grafe, L. I. Gromova, and V. A. Popov, Auroral electrojets during geomagnetic storms, J. Geophys. Res., 102, 14223-14235, 1997.

Greenwald, R. A., K. B. Baker, J. R. Dudeney, M. Pinnock, T. B. Jones, E. C. Thomas, J.-P. Villain, J.-C. Cerisier, C. Senior, C. Hanuise, R. D. Hunsucker, G. Sofko, J. Koehler, E. Nielsen, R. Pellinen, A. D. M. Walker, N. Sato, and H. Yamagishi, DARN/SuperDARN, Space Sci. Rev., 71(1-4), 761-791, 1995.

Iijima, T. and T. A. Potemra, The amplitude distribution of field-aligned currents at northern high latitudes observed by Triad, J. Geophys. Res., 81, 2165-2174, 1976a.

Iijima, T. and T. A. Potemra, Field-aligned currents in the dayside cusp observed by Triad, J. Geophys. Res., 81, 5971-5979, 1976b.

Iijima, T. and T. A. Potemra, Large-scale characteristics of field-aligned currents associated with substorms, J. Geophys. Res., 83, 599-615, 1978.

Kamide, Y., Electrodynamic processes, in The Earth's Ionosphere and Magnetosphere, Kyoto Sangyo University Press, Kyoto, Japan, pp. 156-189, 1988.

Kamide, Y. and S.-I. Akasofu, Latitudinal cross section of the auroral electrojet and its relation to the interplanetary magnetic field polarity, J. Geophys. Res., 79, 3755-3771, 1974.

Kamide, Y. and S.-I. Akasofu, Notes on the auroral electrojet indices, Rev. Geophys., 21, 1647-1665, 1983.

Kamide, Y. and S. Matsushita, Simulation studies of ionospheric electric fields and currents in relation to field-aligned currents, 1. Quiet periods, J. Geophys. Res., 84, 4083-4098, 1979a.

Kamide, Y. and S. Matsushita, Simulation studies of ionospheric electric fields and currents in relation to field-aligned currents, 2. Substorms, J. Geophys. Res., 84, 4099-4115, 1979 b.

Kamide, Y., et al., Global distribution of ionospheric and field-aligned currents during substorm as determined from six IMS meridian chains of magnetometers: initial results, J. Geophys. Res., 87, 8228-8240, 1982a.

Kamide, Y., et al., Changes in the global electric fields and currents for March 17-19, 1978 from six IMS meridian chains of magnetometers, Rep. UAG-87, World Data Center A, Boulder, Colo., 1982b.

$\mathrm{Lu}, \mathrm{G}$. , et al., Interhemispheric asymmetry of the high-latitude ionospheric convection pattern, J. Geophys. Res., 99, 6491-6510, 1994.

Lui, A. T. Y., Current controversies in magnetospheric physics, Rev. Geophys., 39, 535-563, 2001.

Matsushita, S. and W.-Y. Xu, Equivalent ionospheric current systems representing solar daily variations of the polar geomagnetic field, J. Geophys. Res., 87, 8241-8254, 1982.

McPherron, R. L., C. T. Russell, and M. P. Aubry, Satellite studies of magnetospheric substorm on August 15, 1968, 9. Phenomenological model for substorm, J. Geophys. Res., 78, 3131-3149, 1973.

Newell, P. T., The role of the ionosphere in aurora and space weather, Rev. Geophys., 39, 137-149, 2001.

Richmond, A. D., Assimilative mapping of ionospheric electrodynamics, Adv. Space Res., 12, 59-68, 1992.

Sun, W., W.-Y. Xu, and S.-I. Akasofu, Mathematical separation of directly driven and unloading components in the ionospheric equivalent currents during substorms, J. Geophys. Res., 103, 11695-11700, 1998.

Sun, W., W.-Y. Xu, and S.-I. Akasofu, An improved method to deduce the unloading component for magnetospheric substorms, J. Geophys. Res., 105, 13131-13140, 2000.

G.-X. Chen (e-mail: gxchen@mail.igcas.ac.cn), W.-Y. Xu, Z.-G. Wei, B.-H. Ahn, and Y. Kamide 